\title{
Insulin in Bile: Studies on the Effect of Bile Acids on the Radioimmunoassay of Insulin
}

\author{
S.L. JEFFCOATE \\ Novo Research Institute, Copenhagen N, Denmark \\ Received: March 1, 1968
}

\begin{abstract}
Summary. The effect of bile acids on the radioimmunoassay of insulin has been investigated, and the results show that bilo acids in physiological concentrations interfere with the binding of insulin by anti-insulin serum. The dilution curve of immunoreactive insulin in pig gall-bladder bile was not parallel to that of standard pig insulin. After extraction of pig bile with anti-insulin serum and assay of the extract, lower insulin levels were found. The results suggest that only a part of the "immunoreactive insulin" in gall-bladder bile is genuine insulin.
\end{abstract}

Insuline dans la bile: études de l'effet des acides biliaires sur le dosage radio-immunologique de l'insuline

Résumé. L'effet des acides biliaires sur le dosage radioimmunologique de l'insuline a été examiné et les résultats ont montré que les acides biliaires en concentrations physiologiques nuisent à la liaison de l'insuline avec le sérum anti-insulinique. La courbe de dilution de l'insuline immunoréactive dans la bile de la vésicule biliaire porcine n'était pas parallèle à celle de l'insuline porcine standard. Après extraction de la bile porcine par du sérum antiinsulinique et après dosage de l'extrait, des taux d'insu- line plus bas ont été trouvés. Les résultats suggèrent qu'une partie seulement de «l'insuline immunoréactive" de la bile de la vésicule biliaire représente de l'insuline véritable.

Insulin in der Galle: Untersuchung über die Einwirkung von Gallensäuren auf die radio-immunologische Insulinbestimmung

Zusammenfassung. Die Wirkung von Gallensäuren auf die radio-immunologische Insulinbestimmung wurde untersucht. Aus den Resultaten geht hervor, daß Gallensäuren in physiologischen Konzentrationen zu einer Störung der Insulinbindung an Anti-Insulinserum führen. Die Verdünnungskurve von immunoreaktivem Insulin im Gallensaft aus Schweinegallenblasen verlief nicht parallel zur Standard-Eichkurvo von Schweineinsulin. Nach Extraktion der Schweinegalle mit Anti-Insulinserum fanden sich im Extrakt niedrigere Insulinkonzentrationen. Die Ergebnisse deuten darauf hin, daß nur ein Teil des ,immunoreaktiven Insulins" in der Blasengalle echtes Insulin ist.

Key-words: Insulin, radioimmunoassay, bile, bile acids.

\section{Indroduction}

There have been recent reports of the presence of insulin as measured by radioimmunoassay (immunoreactive insulin, IRI) in bile, both from the hepatic duct and from the gall-bladder, of several species (DANIEL and HeNDERSON, 1967; QUIJADA and CANDELA, 1967; QUIJADA and GoNI, 1967). Since bile contains surfaceactive agents, predominantly the bile acids (NoRMAN, 1964), a possible effect of such agents on the binding of insulin by anti-insulin serum should be investigated.

\section{Methods}

Buffer. Dilutions of the samples were made in $0.04 \mathrm{M}$ phosphate buffer, $\mathrm{pH} 7.4$, containing $\mathrm{NaCl}$ $(6 \mathrm{~g} / \mathrm{L})$, bovine albumin $(1 \mathrm{~g} / \mathrm{L})$ and merthiolate $(0.24 \mathrm{~g} / \mathrm{L})$.

Bile acids. A mixture of bile acids (approximately equal amounts of cholic, desoxycholic, glycocholic, desoxyglyeocholic, taurocholic and desoxytaurocholic acids) was prepared" from "Sodium taurocholate, bacteriological" (Edward Gurr, Ltd., London) by chromatography on a column of silica gel in butanolacetic acid-water $(100: 10: 10$, by volume). A stock solution of $200 \mathrm{mg}$ of this bile acid preparation per $\mathrm{ml}$ of phosphate buffer was made, from which solutions containing $0-200 \mu \mathrm{U} / \mathrm{ml}$ of insulin and $2,10,20$ or $50 \mathrm{mg} / \mathrm{ml}$ of bile acid were prepared for assay.

\footnotetext{
1 J. Markussen, Copenhagen.
}

Mouse bile was obtained by aspiration of the gallbladders of ten mice immediately after death; the ten samples were pooled for assay.

$P$ ig bile was obtained from the gall bladders of five pigs at the slaughterhouse within a few minutes of death; the five samples were immediately frozen.

Recovery of insulin added to bile. Recovery tubes were assayed in parallel with bile samples and were prepared by diluting the bile sample with an equal volume of phosphate buffer both with and without pig insulin $(100 \mu \mathrm{U} / \mathrm{ml})$. The recovery tubes were thus equivalent to $0.5 \times$ bile sample $+50 \mu \mathrm{U} / \mathrm{ml}$.

Extraction of bile insulin with anti-insulin serum. $1 \mathrm{ml}$ of bile (containing a tracer amount of ${ }^{125}$ I-insulin) at a final concentration of $1: 3$ was incubated for $3 \mathrm{~h}$ at $4^{\circ} \mathrm{C}$ with guinea-pig anti-insulin serum (binding capacity $2500 \mu \mathrm{U} / \mathrm{ml}$ ). After precipitation with antiguinea-pig gamma-globulin serum the ${ }^{125} \mathrm{I}$ in the precipitate was counted. In the second experiment, $0.2 \mathrm{ml}$ of bile at a final concentration of $1: 10$ was incubated in the same way with a tracer amount of ${ }^{125} \mathrm{I}$-insulin and a large excess of anti-insulin serum (binding capacity $200000 \mu \mathrm{U} / \mathrm{ml}$ ). The precipitated antibody.bound insulin was brought to $\mathrm{pH} 2$ with $0.01 \mathrm{~N} \mathrm{HCl}$ to dissociate the antibody-insulin complex. The antibody was then precipitated with ethanol (final concentration $81 \%$ ) and the supernatant after centrifugation for $10 \mathrm{~min}$ at $2000 \times \mathrm{g}$ was evaporated and counted. Aliquots were then assayed by radioimmunoassay. 
Radioimmunoassy. Standard solutions of pig insulin $(0-200 \mu \mathrm{U} / \mathrm{ml})$ and the samples for assay were incubated with anti-insulin serum at $4^{\circ} \mathrm{C}$ overnight. ${ }^{125} \mathrm{I}$-pig insulin was added, and a further $3 \mathrm{~h}$ incubation

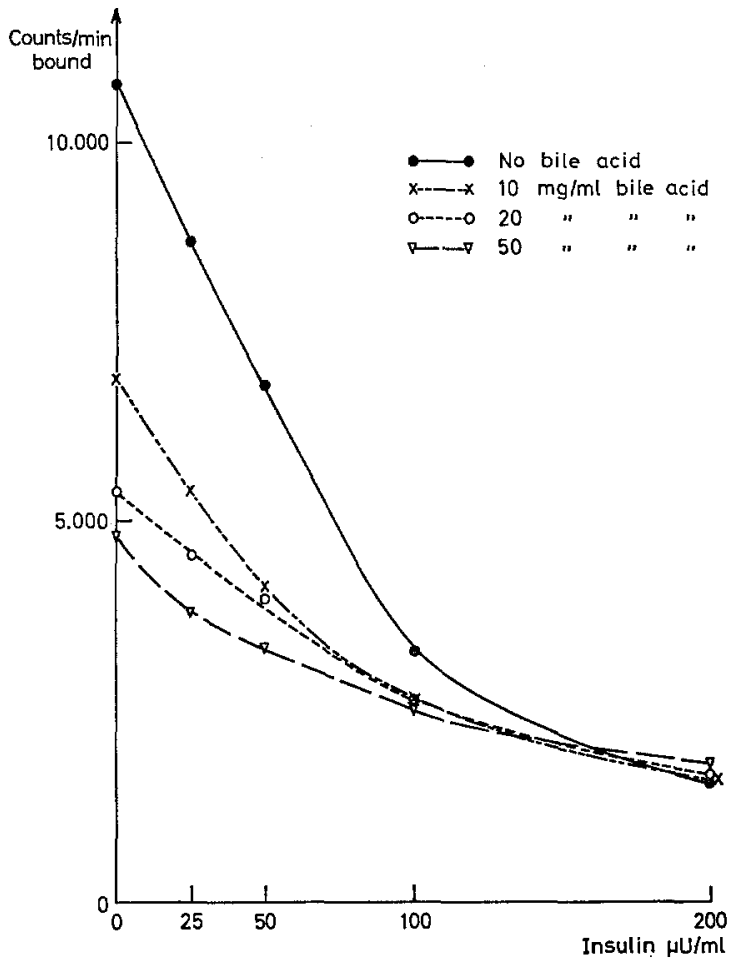

Fig. 1. Radioimmunoassay of insulin (ethanol precipitation method). Standard curves with and without bile acid

carried out. At the end of incubation the free and antibody-bound insulin were separated using three different procedures: (a) ethanol precipitation (HEDING, 1966); (b) double antibody precipitation (method A of HaLES and RANDLe, 1963); (c) paper chromatography in $0.04 \mathrm{M}$ phosphate buffer, pH 7.4, on Whatmann No. $3 \mathrm{MM}$ paper in which free insulin remains adsorbed at the point of application and antibodybound insulin runs to the solvent front. (L. G. HEDING, unpublished)

\section{Results}

Effect of bile acids on radioimmunoassay of insulin. The standard curves of antibody-bound counts against insulin concentration in the presence of increasing amounts of bile acid are shown in Fig. 1 (for ethanol precipitation) and in Fig. 2 (for double antibody precipitation). The effect of bile acid is to reduce the antibody-bound counts at a certain insulin concentration, an effect which is most marked at low concentrations of insulin and which increases with increasing amounts of bile acid. The antibody-bound counts can be plotted against the bile acid concentration at different levels of insulin (Fig. 3, ethanol precipitation data). Even in the absence of insulin there is an apparent dilution curve similar in shape to that of the standard insulin dilution curve.

The effect on the chromatographic method (Fig. 4) is more marked but of a different kind. In the presence

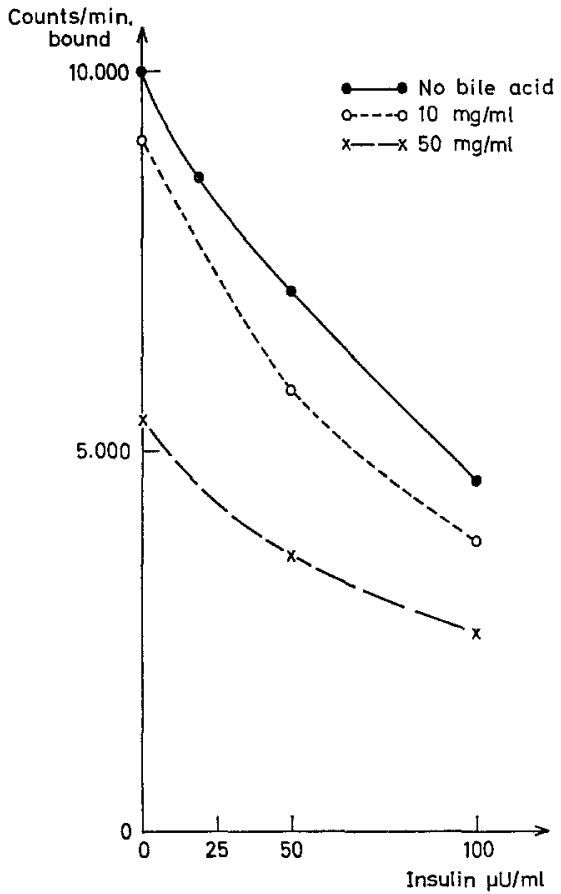

Fig. 2. Radioimmunoassay of insulin (double antibody precipitation method). Standard curves with and without

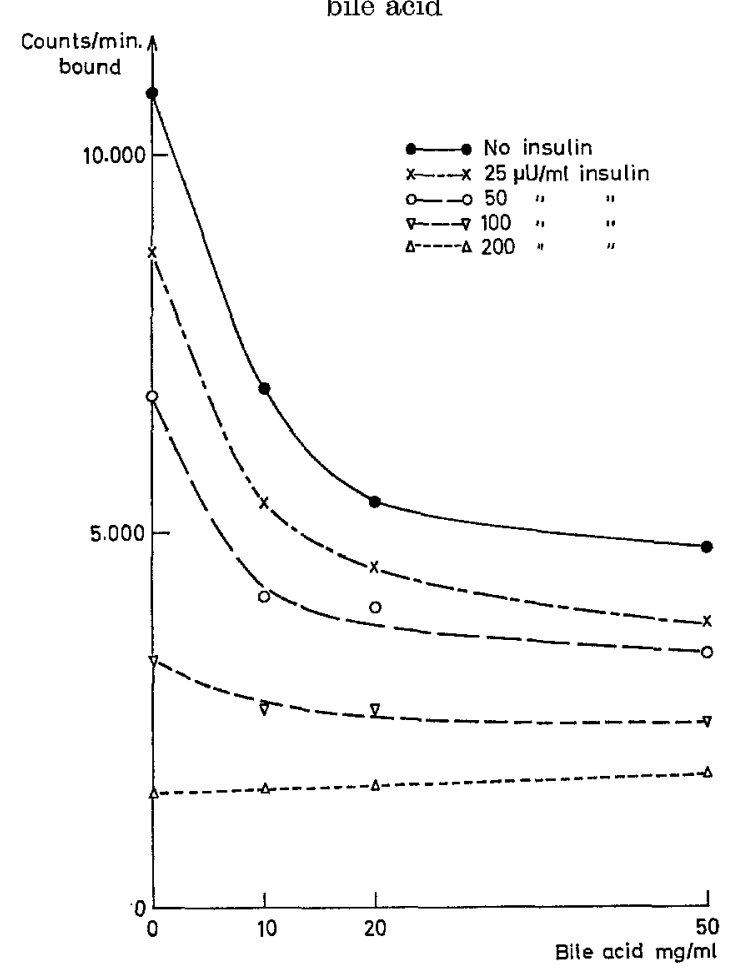

Fig. 3. Radioimmunoassay of insulin (ethanol precipitation method). Antibody-bound counts/minute plotted against bile acid concentration at various insulin concen. trations 
of bile acid, the mobility of free insulin on Whatmann 3 MM paper is increased so that a high proportion appears in the antibody-bound fraction. At a bile acid concentration of $50 \mathrm{mg} / \mathrm{ml}$, over $90 \%$ of the counts are

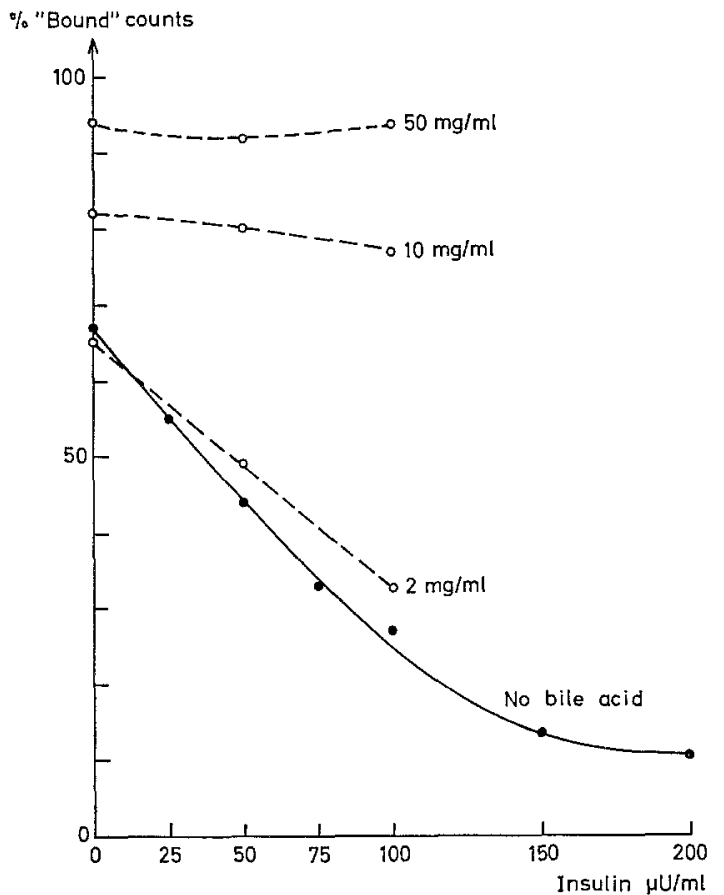

Fig. 4. Radioimmunoassay of insulin (paper chromatographic method). Standard curves with and without bile acid

Table 1. Radioimmunoassay of insulin in pooled mouse gall-bladder bile (ethanol precipitation)

\begin{tabular}{lclc}
\hline $\begin{array}{l}\text { Bile } \\
\text { dilution }\end{array}$ & IRI $\mu \mathrm{U} / \mathrm{ml}$ & $\begin{array}{l}\text { Recovery tube } \\
(\mu \mathrm{U} / \mathrm{ml})\end{array}$ & $\%$ recovery \\
\hline $1: 5$ & 43 & - & - \\
$1: 10$ & 18 & 65 & 94 \\
$1: 20$ & 10 & 61 & 102 \\
$1: 40$ & $<5$ & 59 & $>108$ \\
\hline
\end{tabular}

shown in Fig. 5. Below a bile acid concentration of $2 \mathrm{mg} / \mathrm{ml}$ there is little change in insulin mobility, but between 3 and $6 \mathrm{mg} / \mathrm{ml}$ the percentage that moves from the origin to the front of the paper increases

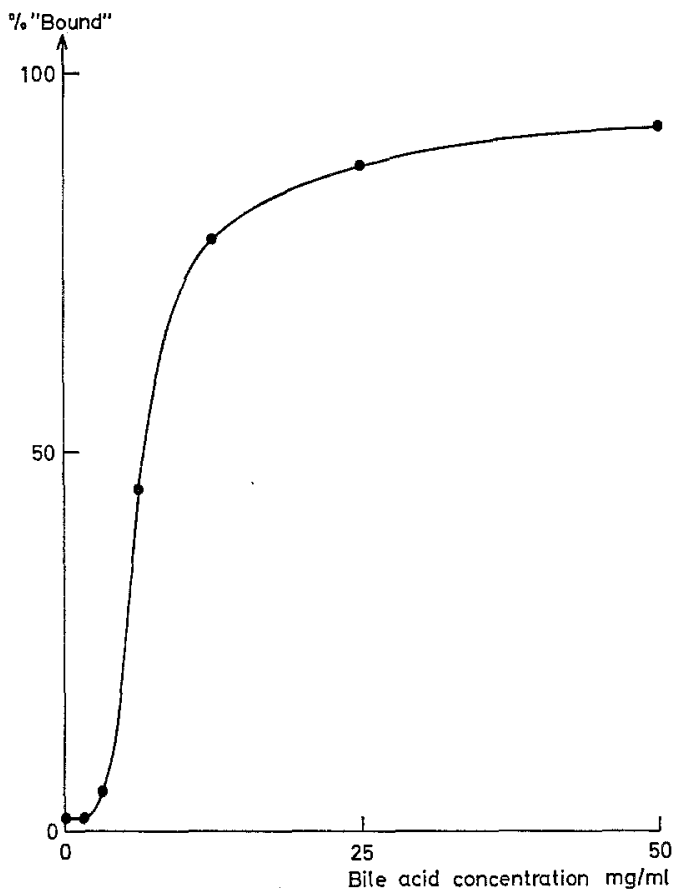

Fig. 5. Effect of bile acid on the mobility of ${ }^{125}$ I-insulin on Whatmann 3 MM paper. "\% bound" $=\%$ of total ${ }^{125} \mathrm{I}$ counts that move from the origin to the solvent front

from 5.5 to 45 . A maximum of about $90 \%$ is reached at $25 \mathrm{mg} / \mathrm{ml}$.

IRI in mouse bile. The levels of IRI found in diluted, pooled mouse bile are shown in Table 1 . The results suggest an insulin concentration of $200 \mu \mathrm{U} / \mathrm{ml}$, with a dilution curve that is parallel to the standard (pig) insulin curve, and with recoveries of added insulin of about $100 \%$. However, when bile at the same dilutions

Table 2. Radioimmunoassay of insulin in five samples of pig gall-bladder bile (double antibody and ethanol precipitation)

\begin{tabular}{|c|c|c|c|c|c|c|c|c|c|c|}
\hline \multirow{3}{*}{ Bile dilution } & \multicolumn{5}{|c|}{ Double antibody method $(\mu \mathrm{U} / \mathrm{ml})$} & \multicolumn{5}{|c|}{ Ethanol precipitation method $(\mu \mathrm{U} / \mathrm{ml})$} \\
\hline & \multicolumn{5}{|c|}{ Bile sample number: } & \multicolumn{5}{|c|}{ Bile sample number: } \\
\hline & 1 & 2 & 3 & 4 & 5 & 1 & 2 & 3 & 4 & 5 \\
\hline $\begin{array}{l}\text { Undiluted } \\
1: 2 \\
1: 4 \\
1: 8 \\
1: 16 \\
1: 32\end{array}$ & $\begin{array}{r}>200 \\
116 \\
85\end{array}$ & $\begin{array}{r}>200 \\
155 \\
98\end{array}$ & $\begin{array}{r}>200 \\
120 \\
86\end{array}$ & $\begin{array}{r}>200 \\
122 \\
87\end{array}$ & $\begin{array}{r}>200 \\
135 \\
94\end{array}$ & $\begin{array}{r}>200 \\
130 \\
97\end{array}$ & $\begin{array}{r}>200 \\
185 \\
118 \\
70 \\
44 \\
17\end{array}$ & $\begin{array}{r}>200 \\
128 \\
103 \\
60 \\
22 \\
9\end{array}$ & $\begin{array}{r}>200 \\
130 \\
103\end{array}$ & $\begin{array}{r}>200 \\
190 \\
123 \\
80 \\
34 \\
5\end{array}$ \\
\hline
\end{tabular}

in the bound fraction irrespective of the insulin concentration.

This effect was further investigated by incubating 125-I-insulin with increasing amounts of bile acid at $4^{\circ} \mathrm{C}$ for $3 \mathrm{~h}$. in the absence of anti-insulin serum. An aliquot was chromatographed, and the results are as used in the assay was incubated with ${ }^{125}$ I-insulin in the absence of anti-insulin serum as above, and the bound and free fractions separated by paper chromatography, the results shown in Fig. 6 were obtained. Even at a dilution of $1: 40,13 \%$ of the added tracer runs to the solvent front. 
IRI in pig bile. The results of the assay of pig bile are shown in Table 2 , and the dilution curves for bile 5 (ethanol precipitation) are shown in Fig. 7. The results obtained by the ethanol precipitation method are consistently higher than those obtained by double antibody precipitation. Both precipitation methods showed that the IRI in pig bile does not have a dilution curve parallel to that of standard pig insulin. The apparent binding as shown by chromatography was tested in the five samples at a bile dilution of $1: 4$, and between $85-95 \%$ of the insulin moved in the bound fraction in the absence of anti-insulin serum.

Table 3. Recovery of insulin added to pig bile (sample No. 1) (a) calculated from recovery tube $-0.5 \times(1: 2$ tube $)$ (b) calculated from recovery tube - (1:4 tube)

\begin{tabular}{llllll}
\hline & \multicolumn{2}{c}{ Bile dilution } \\
$1=2$ 1:4 & $\begin{array}{l}\text { Recovery } \\
\text { tube } \\
(\mu \mathrm{U} / \mathrm{ml})\end{array}$ & \multicolumn{2}{c}{$\begin{array}{l}\text { \% recovery } \\
(\mu \mathrm{U} / \mathrm{ml})\end{array}$} & (a) & (b) \\
\hline $\begin{array}{l}\text { Double } \\
\text { antibody }\end{array}$ & 116 & 85 & 110 & 104 & 50 \\
Ethanol & 130 & 97 & 117 & 104 & 40 \\
\hline
\end{tabular}

a Recovery tube contained bile diluted $1: 2$, further diluted with an equal volume of pig insulin $(100 \mu \mathrm{U} / \mathrm{ml})$.

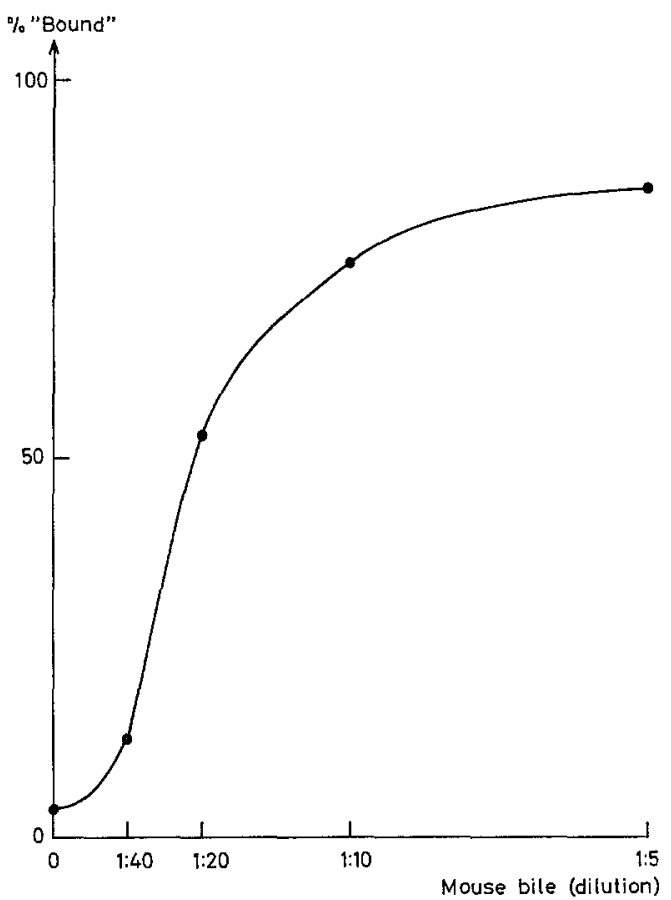

Fig. 6. Effect of increasing concentration of mouse bile on the mobility of ${ }^{125}$ I-insulin. See Fig. 5

Recovery of added insulin. Bile diluted 1:2 with buffer was further diluted with an equal volume of pig insulin $(100 \mu \mathrm{U} / \mathrm{ml})$. The results for bile 1 (the others were similar) are shown in Table 3 . Recovery of added insulin was $100 \%$ when calculated as

$$
\frac{\text { recovery tube }-0.5 \times(\text { bile } 1: 2)}{50} \times 100
$$

but only $40-50 \%$ when calculated as

$$
\frac{\text { recovery tube }-(\text { bile } 1: 4)}{50} \times 100 \text {. }
$$

Since the two methods of calculation shoud give the same answer for the percentage recovery, this further suggests that the apparent IRI in bile is not all genuine insulin.

Extraction of pig bile with anti-insulin serum. When $1 \mathrm{ml}$ bile at a final dilution of $1: 3$ was extracted with anti-insulin serum only $10 \%$ of the added tracer was

Table 4. Radioimmunoassay (ethanol precipitation) of insulin in pig bile before and after extraction with anti-

\begin{tabular}{|c|c|c|c|c|c|c|}
\hline $\begin{array}{l}\text { Bile } \\
\text { No.: }\end{array}$ & $\begin{array}{l}\text { Une } \\
\text { bile } \\
(\mu \mathrm{U}) \\
1: 2\end{array}$ & $\begin{array}{l}\text { racted } \\
1: 5\end{array}$ & $\begin{array}{l}\text { Ext } \\
\text { bile } \\
(\mu \mathrm{C} \\
1:\end{array}$ & $\begin{array}{l}\text { ted. } \\
1: 5\end{array}$ & $\begin{array}{l}\text { \% reco- } \\
\text { very of } \\
\text { added } \\
\text { tracer }\end{array}$ & $\begin{array}{l}\text { Calculated } \\
\mu \mathrm{U} / \mathrm{ml} \text { bile }\end{array}$ \\
\hline 1 & 117 & 85 & 35 & 19 & 61 & 152 \\
\hline 2 & 160 & 110 & 25 & 12 & 49 & 124 \\
\hline 3 & 119 & 92 & 37 & 20 & 59 & 164 \\
\hline 4 & 121 & 95 & 36 & 17 & 55 & 161 \\
\hline 5 & 164 & 112 & 29 & 15 & 59 & 125 \\
\hline
\end{tabular}
insulin serum

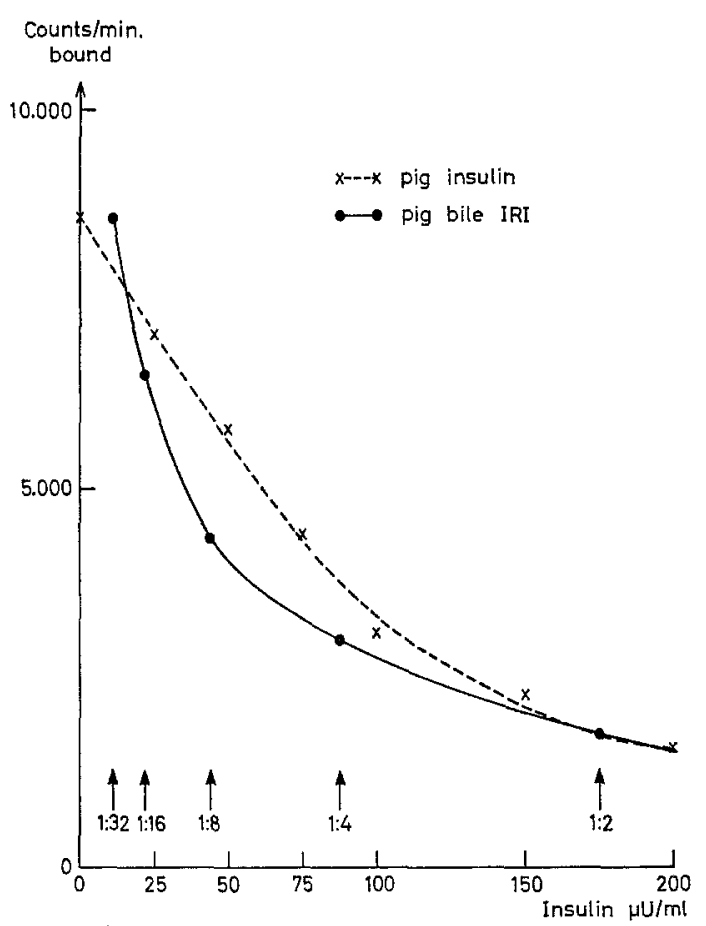

Fig. 7. Pig insulin standard curve and dilution curve of pig bile (sample 5)

bound to antibody. This indicates an inhibition by bile of the binding of insulin by antibody. When bile diluted 1:10 was extracted with a great excess of antibody, $50-60 \%$ of the tracer insulin was recovered after removal of the antibody. The assay results (ethanol precipitation) of these extracts, freed from other bile constituents, compared with unextracted bile are shown in Table 4. After extraction, the levels 
of IRI were lower, and a twofold dilution halved the concentration of IRI. If it is assumed that the percentage recovery of the added tracer represents the recovery of the bile insulin, then the calculated levels of IRI in pig bile were $124-165 \mu \mathrm{U} / \mathrm{ml}$.

\section{Discussion}

WeETaLL and Bozicevich (1967) have recently shown that two surfactants ("Tween" 80 and "Gantrez AN-119)" inhibit the precipitation reaction between bovine serum albumin (BSA) and anti-BSA sera. The concentration of bile acids, the predominant surface active agents of bile, in human gallbladder bile is $38 \pm 21 \mathrm{mg} / \mathrm{ml}$ (NaKAYAMA, 1967), and the results presented here show that within this concentration range bile acids have a pronounced effect on the radioimmunoassay of insulin. The effect on the ethanol and doubleantibody precipitation methods is to lower the antibody-bound counts thus giving a falsely high IRI value.

Using the HALES and RANDLE (1963) method, DANIEL and HENDERSON (1967) found mean IRI levels in gall-bladder bile of $1780 \mu \mathrm{U} / \mathrm{ml}$ in rabbits and 1981 $\mu \mathrm{U} / \mathrm{ml}$ in monkeys. This was $80-100$ times the levels in peripheral venous blood. Levels in hepatic bile (which contains $20-30 \%$ the concentrations of bile acids as gall-bladder bile). were only twice the blood levels. Using the same technique, however, QUIJADA and GoNI (1967) found much lower gall-bladder bile IRI values: a mean of $181 \mu \mathrm{U} / \mathrm{ml}$ in rabbits, and values of $100 \mu \mathrm{U} / \mathrm{ml}$ or below in dog, cat, ox, sheep, swine and chicken.

The results for mouse and pig gall-bladder bile found in this study are closer to those of QUIJADA and GONI, but indicate that any estimate of IRI in bile should be interpreted with caution. Thus the dilution curve of pig bile IRI was not parallel to that of the standard pig insulin curve. After extraction of the insulin from other bile constituents, however, a twofold dilution halved the IRI value. The need to dilute bile before obtaining adequate recoveries of insulin from bile using anti-insulin serum is a further indication of an inhibitory effect of bile on the binding of insulin to its antibody.

The conclusion of WeETALL and BozIOEVICH (1967) that the "necessity of carefully considering the possible effects a surfactant may have when added to biological systems" seems to be relevant here, and the possible dangers of applying an immunological assay method designed for blood plasma to other body fluids should be borne in mind.

\section{References}

Daniel, P.M., and J.R. Henderson : Insulin in bile and other body fluids. Lancet 1967 I, 1256-1257.

Hates, C.N., and P.J. RandLe: Immunoassay of insulin with insulin antibody precipitate. Biochem. J. 88, $137-146(1963)$.

HeDrra, L.G.: A simplified insulin radioimmunoassay method. Proceedings of Conference on Problems Connected with the Preparation and Use of Labelled Proteins in Tracer Studies, p. 345 - 350. Pisa: 1966.

NaKayama, F.: Quantitative analysis of bile. J. Lab. clin. Med. 89, 594-609 (1967).

Norman, A. : Application of gel filtration of bile acids to studies of lipid-complexes in bile. Proc. Soc. exp. Biol. 116, 902-905 (1964).

QUIJADA, C.L., and J.L.R. CANDELA. Insulin and insulinlike activity in the bile of rabbits. Proc. Soc. exp. Biol. (N.Y.) 126, 209-212 (1967).

-, and P.M. GoNr: Liver and insulin: presence of insulin in bile. Metabolism 16, 514-521 (1967).

WEETALI, H.H., and J. Bostcevich: Effect of surfactants on antigen-antibody reactions. Nature (Lond.) 215, $1479-1480$ (1967).

S.L. Jeffcoate, M.B., Ph.D.

Novo Research Institute

Copenhagen $\mathrm{N}$

Denmark 